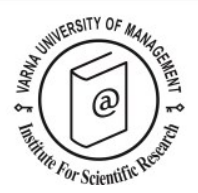

\title{
Classification of hotel performance measurement indicators presented in international scientific research
}

\author{
Kyriaki Pnevmatikoudi ${ }^{1}$ and Theodoros Stavrinoudis ${ }^{1 *}$
}

Received: 06/04/2015 Accepted: 05/10/2015

\footnotetext{
${ }^{1}$ University of the Aegean, Department of Business Administration, 8 Michalon str., 82100 Chios, Greece, phone: +30 6938799541

* Corresponding author: e-mail: tsta@aegean.gr
}

\begin{abstract}
The present manuscript studies and classifies the different performance variables and measures of hotels, recorded in international scientific journals. Through the Content Analysis of 79 scientific papers, this manuscript reaches a main conclusion regarding hotel performance indicators measurement. Although researchers have acknowledged that the concept of hotel performance is complex and manifold (and as such it is depicted and assessed with various and diverse indicators and groups of indicators in international scientific literature), still the majority of them measure hotel performance in a way that does not express its multidimensional nature in their studies as they focus on a relatively small number of the above indicators. This paper mainly contributes to further classifying hotel performance indicators and introduces a novel codification that allows researchers to better understand indicators and hotel executives to use them more effectively.
\end{abstract}

(C) 2016 Varna University of Management. All rights reserved

Keywords: hotel performance, performance measurement, indicators, classification, content analysis

Citation: Pnevmatikoudi, K., T. Stavrinoudis (2016) Classification of hotel performance measurement indicators presented in international scientific research. European Journal of Tourism Research 12, pp. 82-98

\section{Introduction}

The concept of performance is of major significance as it lies in the core of business strategy, affects the competitive position (Claver-Cortes, Molina-Azorin and PereiraMoliner, 2006; Venkatraman and Ramanujam, 1986) and determines the long-term economic sustainability of firms (Neves and Lourenco, 2009). Consequently, performance and its measurement are key factors to every tourism enterprise's success. This is established and reflected in the emphasis that a vast amount of international researches and papers in the field of hospitality put over the past few years to performance and its measurement (Kim, Cho and Brymer, 2013; Oliveira, Pedro and Marques, 2013; Ratsimbanierana, Sbai and Stenger, 2013; Sainaghi, Phillps and Corti, 2013; Sourouklis and Tsagdis, 2013; Li, Sanders and Frenkel, 2012; Marco, 2012; 
Rahman, Dayang-Affizzah and Edman, 2012; Xiao, O'Neill and Mattila, 2012; Assaf and Barros, 2011; Assaf and Cvelbar, 2011; Chen, 2011; Sozuer, 2011; Wu, Tsai and Zhou, 2011; Chen, 2010; Fisher, McPhail and Menghetti, 2010; Hsieh and Lin, 2010; Sainaghi, 2010). Performance as conceptualization and operationalization has always been an ambiguous concept in the literature of business administration related to both corporate management and hospitality industry (ClaverCortes, Molina-Azorin and Pereira-Moliner, 2006). Consequently, taking into consideration the special characteristics of performance, its complex-multidimensional nature (ClaverCortes, Molina-Azorin and Pereira-Moliner, 2006) as well as its significance, it is no surprise that there is such a vast number of approaches in international business research and journals dealing with the concept of performance in general (Hult et al., 2008) and hotel performance in particular: its categorization and definition; its evaluation techniques; and its specific indicator measurement (Karatepe, 2013; Assaf, Josiassen and Cvelbar, 2012; Karatepe, 2012; Chen, Hsu and Tzeng, 2011; Kang, Lee and Huh, 2010; Wadongo et al., 2010; Neves and Lourenco, 2009; Phillips, 1999b). According to Kaplan and Norton (1992, p. 71) "What you measure is what you get", given that the organization's measurement system affects the behavior of employees and managers. Therefore, the performance measurement system should be aligned with and reflect the various goals of a company. For all these reasons, it is considered vital for performance measurement systems to reflect the complex nature of the service delivery process within hotels (Garrigos-Simon, Palacios-Marques and Narangajavana, 2005; Atkinson and Brander Brown, 2001).

Throughout this manuscript it is assumed that "the hotel's performance is the aggregated efforts of different departments, involving both the front of the house and the back of the house" (Hsieh and Lin, 2010, p. 14).

Various authors, including Chen, Hsu and Tzeng, (2011); Wadongo et al., (2010); Bolat and Yilmaz, (2009); Espino-Rodriguez and Padron-Robaina, (2005); Garrigos-Simon,
Palacios Marques and Narangajavana, (2005); Haktanir and Harris, (2005), et al., acknowledged the need for clarification and codification of hotel performance measurement indicators. These authors attempted to subsume selected indicators into groups. However, none of the existing research attempts has included all the indicators recorded in the relative literature. In addition, none of the existing research attempts has dealt in detail with both groups of financial/economic and non-financial/economic indicators. The present manuscript aims to partly fill this gap. Based to some extent on the existing classifications (on the one hand of Financial Statement Analysis literature, which deals with groups of financial indicators, and on the other hand of hotel performance related literature, which focuses on either financial or non-financial groups of indicators), it makes the necessary adjustments by suggesting a new clustering which takes into consideration all the indicators found in the international literature.

This manuscript pushes forward the codification of hotel performance that other papers have used in the past. It adopts a thorough classification of the financial indicators cited in related papers, using as a basis the Financial Statement Analysis assessment of seven basic indicator groups. One of its major contributions is the fact that the researchers build upon it a novel classification by modifying the already existing indicator groups and adding new ones, taking into consideration the particularities of hotel performance and the approaches of the related papers. This paper concludes with the division of financial indicators into ten groups (see more in section 3.1 Financial hotel performance indicators).

The proposed classification responds fully to the situation, needs and particularities of the hospitality sector and hotel management. It is a holistic approach to codify all indicators measuring hotel performance, which is crucial for hotel sustainability. Having studied a great number of scientific opinions and approaches, a new point of view of performance measurement and codification was developed. Its objective is to give hotel managers a tool for easier information on selection and 
implementation of the right indicators that can provide constant and accurate details on the performance of their hotels.

The main objective of this manuscript is to capture and suggest a novel codification and classification of the variables measuring hotel performance, based on the related international scientific research. It codifies the existing indicators, suggests new ones and presents an original categorization of hotel performance, which includes registers of all the existing hotel performance indicators, emphasizing both groups of financial and non indicators. The accomplishment of this goal is attempted by carrying out the following research objectives: a) recording all of the hotel performance measurement indicators identified in the related literature; and b) suggesting a new encompassing codification that leads to the creation of an original classification of indicators into different groups. The present analysis offers researchers the ability to have a quick overview of hotel performance measurement indicators in international literature, covering a substantial period of time, i.e. from 1985 to 2013.

\section{Methodology}

Given the purpose of the manuscript and in order to fulfill the research objectives, the existing related international researches and papers were gathered and examined. To identify papers-researches for review, an online search of all major databases was conducted. The keywords used were related to the sector (hotels-hospitality) and to the topic of this manuscript (performance). The research was conducted from the beginning of April 2013 until January 2015. Only papers published in English have been considered in the sample with their total number amounting to 99. Excluding the papers that did not serve the objective of this manuscript, the final sample was composed of 79 papers, which were analyzed using the method of Content Analysis.

Content Analysis is a scientific research method mostly used in humanities and social sciences (Krippendorff, 2013). It is widely used among researchers who desire to review the literature and research related to a particular issue. The paper of Hult et al. (2008) is a good example that makes an assessment of the measurement of performance in international business research by using Content Analysis. In the journals surveyed, examples of Content Analysis usage were detected by researchers that focus on the wider approach of hotel performance and its measurement. More specifically, Sainaghi (2010) attempted to investigate how success of a hotel business is measured and to identify the factors that determine performance. Teare (1996) investigated the patterns in management, service improvement and business performance in hospitality, reviewing papers published during 1995 in specific journals. Content Analysis was used in this research as it was considered the most appropriate technique to investigate and analyze the way that hotel performance measurement is approached by literature. The papers of Sainaghi (2010); Werner and Ward (2004) and Teare (1996), also account for the methodological basis of this paper. For better understanding, analyzing and categorizing of financial indicators in particular, it was considered necessary to examine the literature on Financial Statement Analysis that deals with such indicators per se.

\section{Classification of hotel performance measurement indicators}

In international scientific literature a wide range of variables/measures and indicators is identified and recorded, according to which hotel performance is evaluated and measured. This range renders it necessary to classify and codify the presentation of indicators into different groups. This was attempted by various researchers including Chen, Hsu and Tzeng (2011); Wadongo et al. (2010); Bolat and Yılmaz (2009); Espino-Rodriiguez and PadronRobaina (2005); Garrigos-Simon, PalaciosMarques and Narangajavana (2005); Haktanir and Harris (2005), who classified selected indicators into separate groups. The present manuscript takes into consideration, is partly based on and utilizes said classifications. It proceeds, however, with diversifications forming a more complete classification, which aims to include all the indicators identified in the international scientific literature. This new classification was based on the Financial 
Statement Analysis literature (Kantzos, 2013; Wild, Subramanyam and Halsey, 2007; Niarchos, 2004; Fridson and Alvarez, 2002; Bernstein and Wild, 1998) and the hotel performance-related literature (Chen, Hsu and Tzeng, 2011; Wadongo et al., 2010; Bolat and Yılmaz, 2009; Espino-Rodriguez and PadronRobaina, 2005; Garrigos-Simon, PalaciosMarques and Narangajavana, 2005; Haktanir and Harris, 2005) and it only emerged after researchers realized the necessary modifications and additions to indicator groups, so that the new classification can be clear and complete.

Within this framework, the financial dimension was first investigated as it is the most widespread dimension of performance (Wadongo et al., 2010; Garrigos-Simon, Palacios-Marques and Narangajavana, 2005; Atkinson and Brander Brown, 2001; Phillips, 1999b; see also Han, 2012; Marco, 2012; Palacios-Marques, Ribeiro-Soriano and GilPechuan, 2011; Chen, 2010; Jung, 2008; Claver-Cortes, Molina-Azorin and PereiraMoliner, 2006: Sharma and Upneja, 2005; Banker, Potter and Srinivasan, 2005; Phillips, 1999; Curry, 1985). It is this dimension that diversifies the indicators between financial/economic and non-financial/economic or mainly qualitative (basic first level classification of indicators). The new classifications presented in this manuscript emphasize groups of both financial and nonfinancial indicators. Aiming at a more rigorous classification of indicators, separate indicator groups were developed and presented in Table1.

These groups emerged according to the classifications of the existing literature in combination with the codification-classification applied by the researchers, which was mainly based on the title and content of each indicator, given that there is no generally accepted classification in the international literature. In detail, after recording the indicators that were identified in the 79 articles dealing with hotel performance and its measurement, they were divided into distinct groups, while at the same time reporting on the frequency of their appearance and more specifically the number of papers (column 4) and of particular source papers (column 5). The above process led to twenty indicator groups including a total of 119 indicators. Column 3 of Table 1 illustrates the indicators incorporated in each group, according to their frequency of appearance in researches. It should be specified that each indicator is incorporated into one and only group.

The following sections cite the analysis which clarifies the classification suggested by researchers.

\section{Financial hotel performance indicators}

Regarding the financial/economic indicators and utilizing the literature on Financial Statement Analysis, it is established that most authors (Kantzos, 2013; Wild, Subramanyam and Halsey, 2007: Niarchos, 2004; Fridson and Alvarez, 2002; Bernstein and Wild, 1998) agree, with minor insignificant differentiations, that financial indicators can be divided into 6 basic groups: 1) "Return on invested capital indicators", 2) "Profitability indicators", 3) "Utilization or activity indicators", 4) "Liquidity indicators", 5) "Capital structure and solvency indicators" and 6) "Financial market or investment indicators" (Wild, Subramanyam and Halsey, 2007; Fridson and Alvarez, 2002: Bernstein and Wild, 1998). Kantzos (2013) and Niarchos (2004) also highlight the group "Operating expenses". It was ascertained that the objectives of this study cannot be satisfied by completely adopting this grouping. On that account, the authors of the present manuscript on the one hand take the specific grouping into account; on the other hand though they proceed with the necessary modifications and additions for an original classification of financial indicators to emerge. And they do so according to an adjustment of the new classification to the particularities regarding the financial performance of hotel enterprises.

The literature on hotel performance revealed that various researchers (Chen, Hsu and Tzeng, 2011; Wadongo, et al., 2010; EspinoRodriiguez and Padron-Robaina, 2005; Haktanir and Harris, 2005) incorporate all financial indicators into one group under the title "financial performance" or other similar titles without further dividing them into groups. 


\begin{tabular}{|c|c|c|c|c|c|c|c|}
\hline \multicolumn{6}{|c|}{ Financial indicators } & \multirow{2}{*}{ 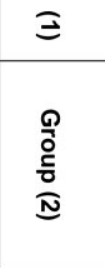 } & \\
\hline 商 & 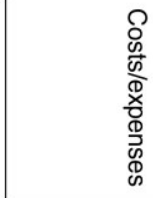 & 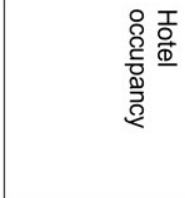 & 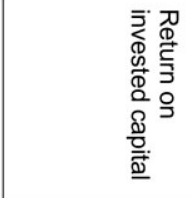 & 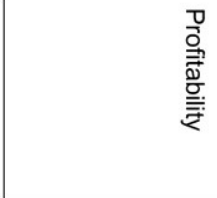 & 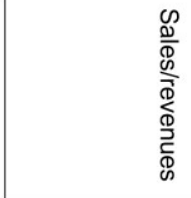 & & \\
\hline 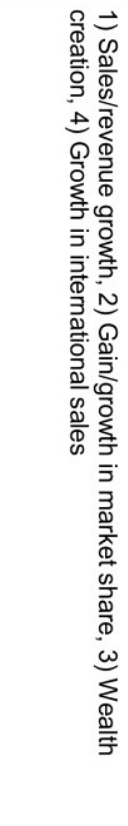 & 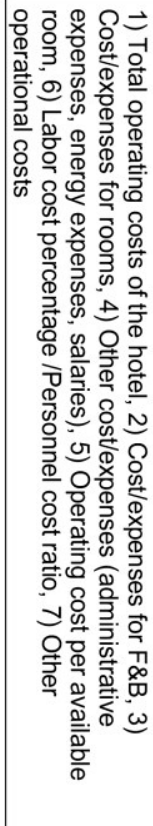 & 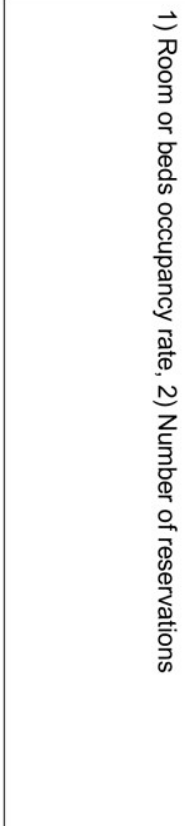 & 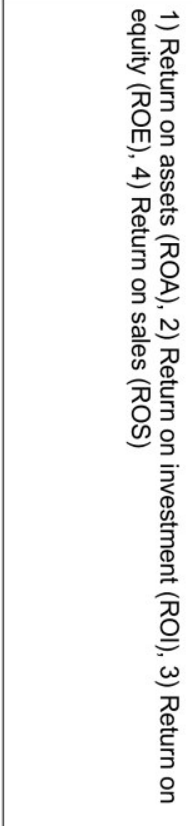 & 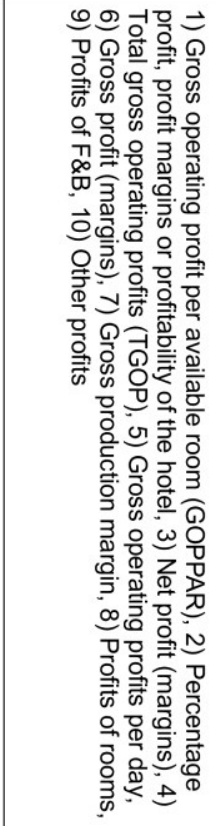 & 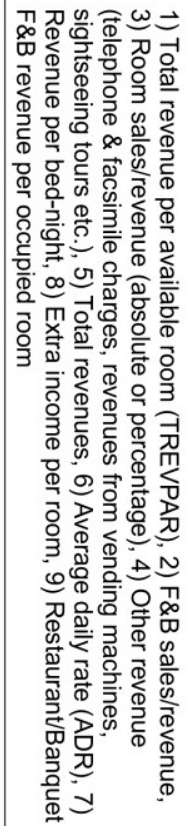 & 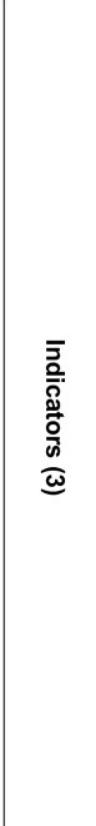 & \\
\hline$v$ & 0 & $\vec{\omega}$ & $\vec{\omega}$ & $\vec{A}$ & $\vec{v}$ & 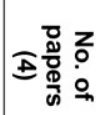 & \\
\hline 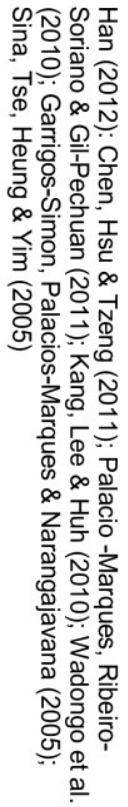 & 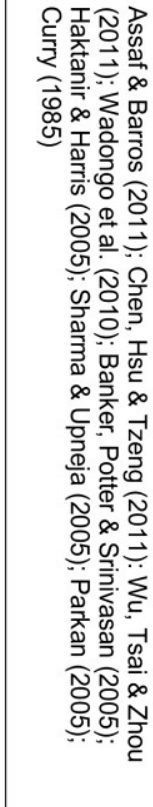 & 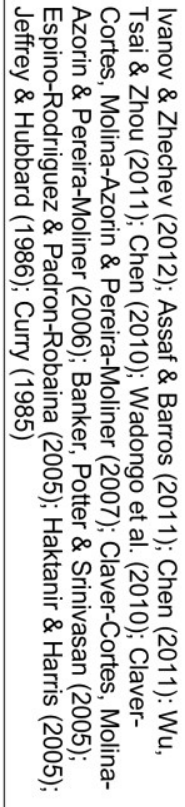 & 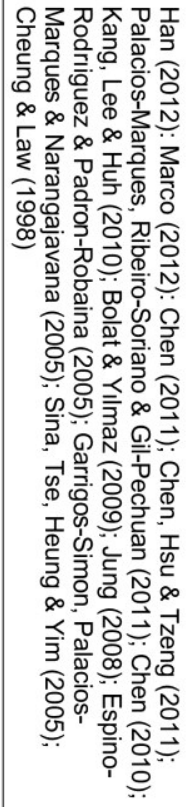 & 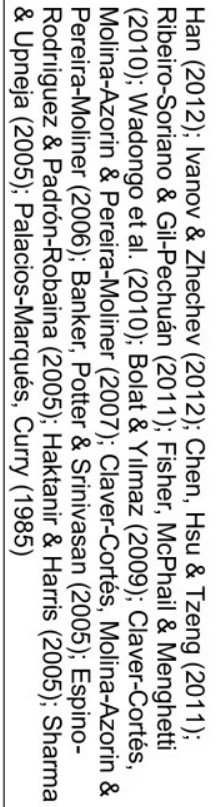 & 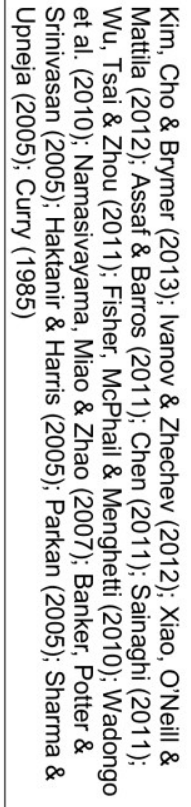 & 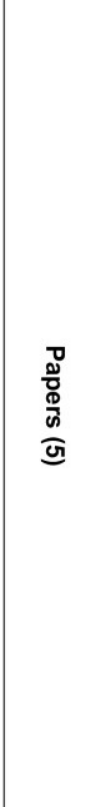 & \\
\hline
\end{tabular}


Pnevmatikoudi, K., T. Stavrinoudis (2016) / European Journal of Tourism Research 12, pp. 82-98

\begin{tabular}{|c|c|c|c|c|c|c|}
\hline \multicolumn{3}{|c|}{ Non financial indicators } & \multirow{2}{*}{\multicolumn{2}{|c|}{ 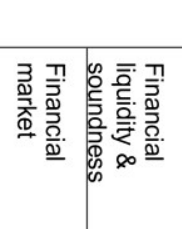 }} & \multirow[b]{2}{*}{ 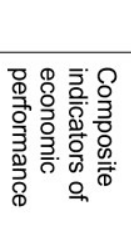 } & \multirow[b]{2}{*}{ 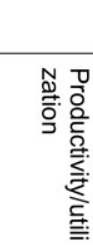 } \\
\hline 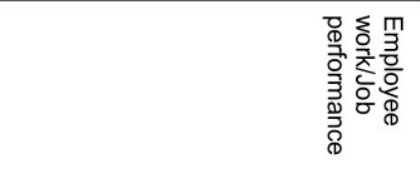 & 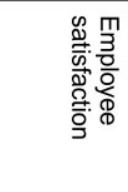 & 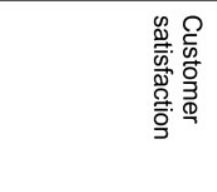 & & & & \\
\hline 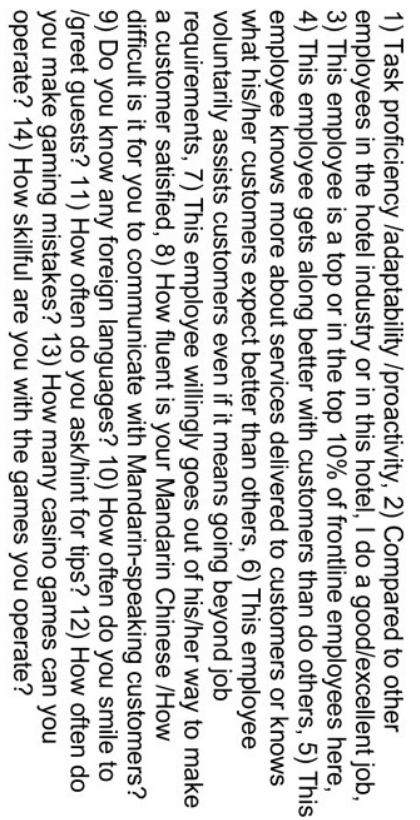 & 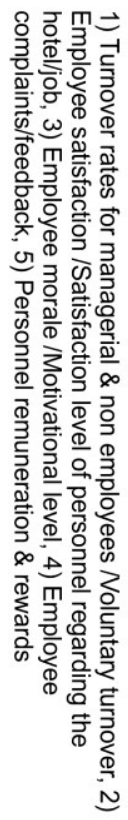 & 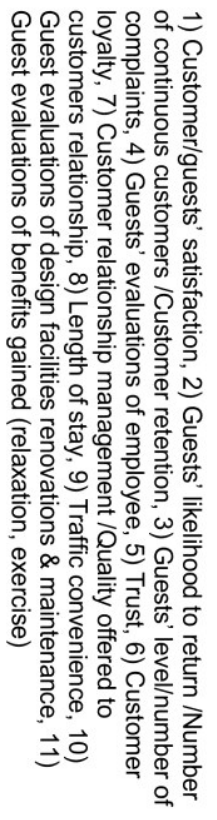 & 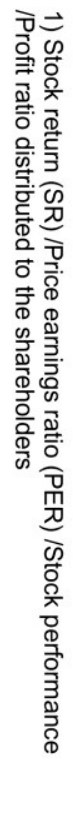 & 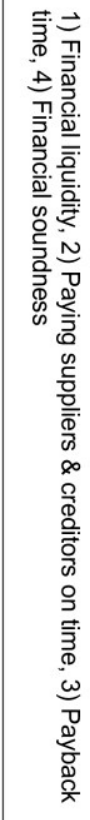 & 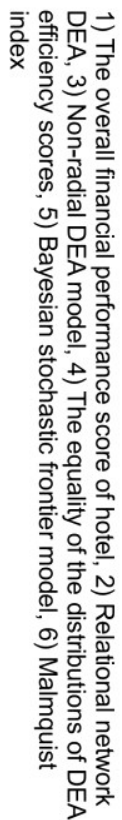 & 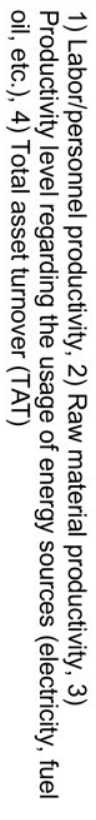 \\
\hline A & $v$ & $\vec{\Delta}$ & $\Delta$ & or & a & a \\
\hline 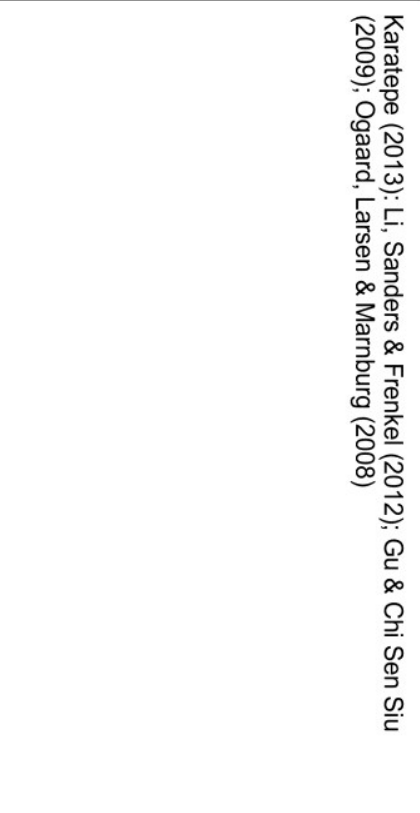 & 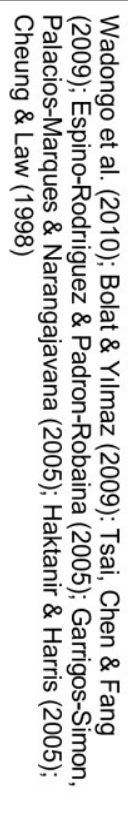 & 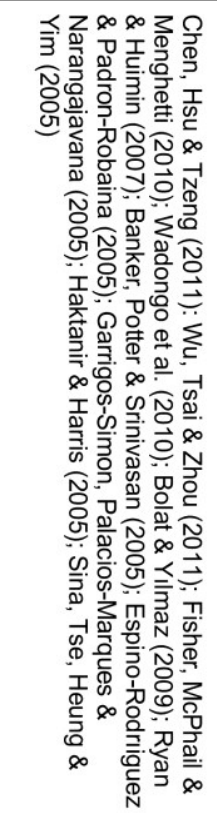 & 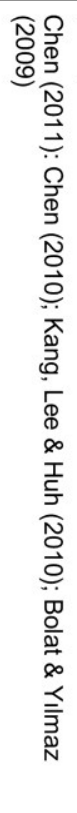 & 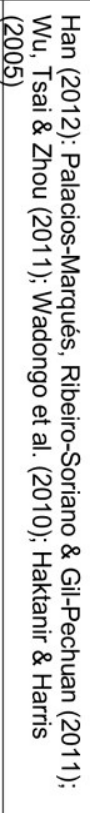 & 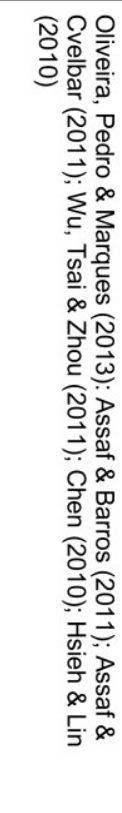 & 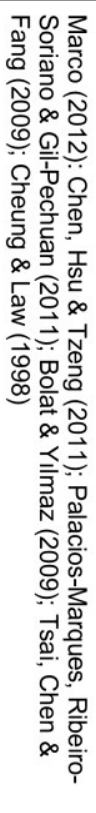 \\
\hline
\end{tabular}


Classification of hotel performance measurement indicators presented in international scientific research.

\begin{tabular}{|c|c|c|c|c|c|c|}
\hline 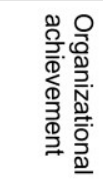 & $\begin{array}{l}\frac{T}{\mathbb{D}} \\
\stackrel{x}{\bar{\sigma}} \\
\underline{\bar{E}}\end{array}$ & 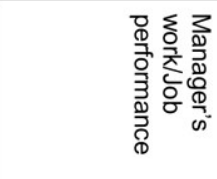 & 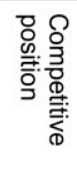 & 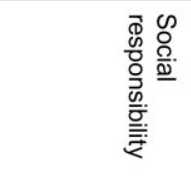 & 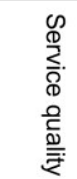 & 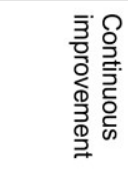 \\
\hline 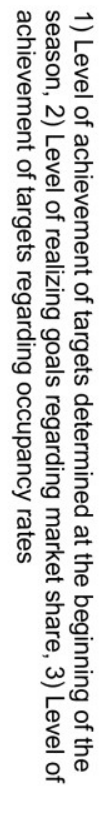 & 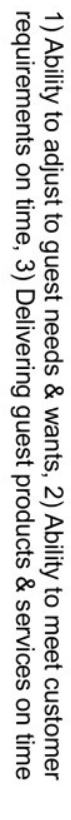 & 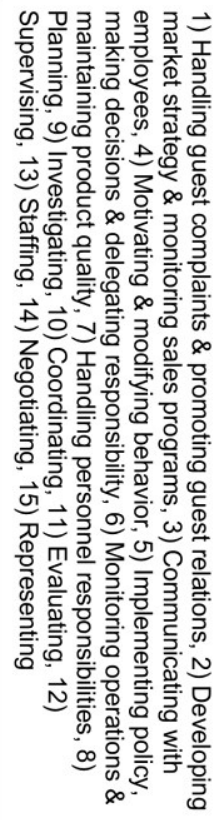 & 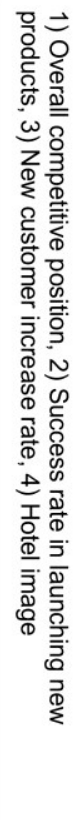 & 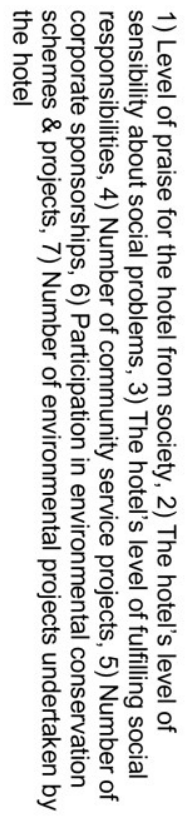 & 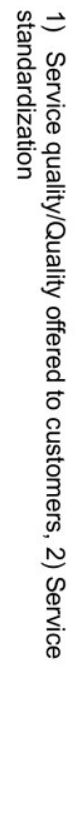 & 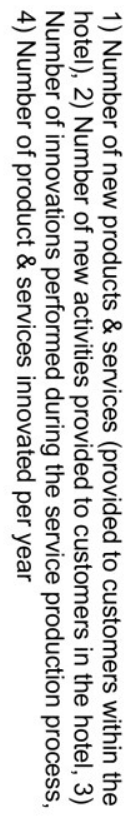 \\
\hline$\rightarrow$ & $\rightarrow$ & $N$ & $N$ & $N$ & $\omega$ & $\omega$ \\
\hline 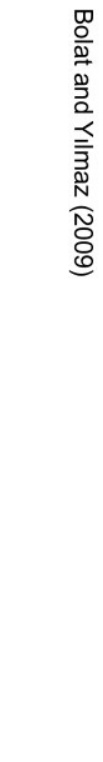 & 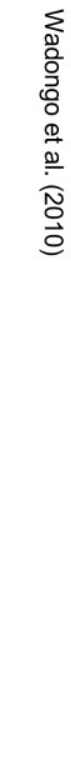 & 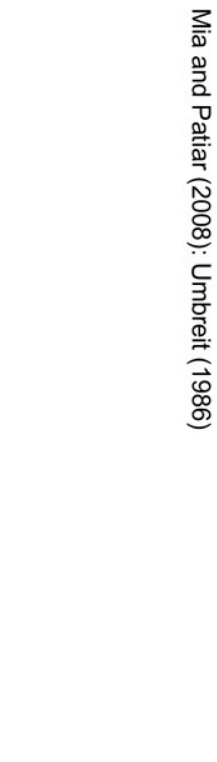 & 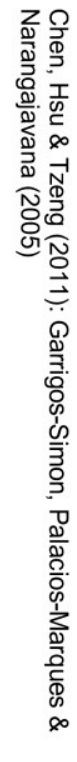 & 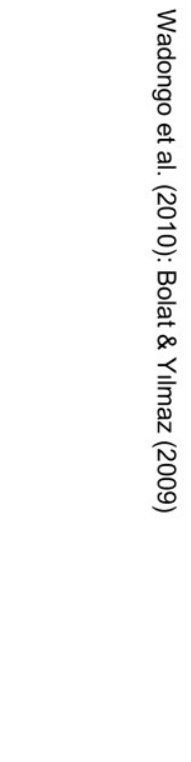 & 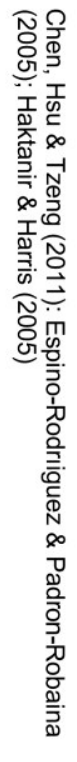 & 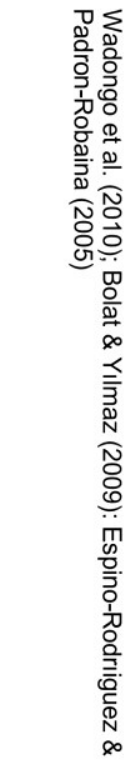 \\
\hline
\end{tabular}


It is this generalized approach that other researchers aim to specialize to some extent, by attempting to divide the financial indicators into separate groups. For example, GarrigosSimon, Palacios-Marques and Narangajavana (2005) distinguish between financial indicators referring to "Profitability" (including in this group indicators such as "ROA", "ROI", "ROS" etc.) and those referring to "Growth" (indicators such as "Growth in sales", "Market share increase" and "Wealth creation"), while Bolat and Yılmaz (2009) recognize the group "Profitability" and add the group "Productivity" (indicators such as "Raw material productivity", "Productivity level of personnel" and "Productivity level regarding the usage of energy sources"). Nevertheless, the above classification attempts of financial indicators are fragmentary and do not conform to the theory of Financial Statement Analysis that traditionally deals with financial indicators. These facts render said attempts difficult to offer a sufficient, clear and complete classification of financial performance indicators for hotels. In recent years, the attention of many researchers has focused on Hotel Revenue Management (Ivanov, 2014; Mauri, 2013; Ivanov and Zhechev, 2012; Hayes and Miller, 2011; Maier, 2011; Kimes, 2009; Mauri, 2007). According to Ivanov (2014, p. 43) "Hotel Revenue Management uses various metrics that show the effectiveness and the efficiency of the hotel to generate revenues". Under this point of view, researchers usually analyze from the total of financial measures/variables only those related to revenue performance used and classified by the different revenue centers-divisions of the hotel (Ivanov, 2014).

The present manuscript adopts a thorough classification of the financial indicators cited in related papers. This approach concludes with the division of financial indicators into ten separate groups (illustrated in table 1, column 2) reporting at the same time the frequency of their appearance in the available studies.

More specifically, the indicator group "Return on invested capital" stands out. In the case of hotels, researchers focus on the corresponding indicators of table 1 , column 3 . The above indicator group is called by some researchers of hotel performance "Profitability" (e.g.
Garrigos-Simon, Palacios-Marques and Narangajavana, 2005), which is not perfectly aligned with the majority of the researchers in Financial Statement Analysis. Most researchers believe that the group "Profitability" includes several indicators (Kantzos, 2013; Wild, Subramanyam and Halsey, 2007: Bernstein and Wild, 1998).

As regards the indicator group "Profitability", researchers of hotel performance focus on the indicators illustrated in table 1 . It should be noted here that researchers, both from the field of hotel performance (Bolat and Yilmaz, 2009) and from the field of Financial Statement Analysis (Niarchos, 2004), have incorporated into the group "Profitability" indicators that belong both in the "Profitability" group (as described above) and in the group "Return on invested capital". This above approach has not been adopted by this study. The researchers have chosen to divide the indicators into two distinct and clear groups. The above choice was made because in the hotel industry it is particularly important to have a clear idea about the financial benefits of hotels in regard to activities/operations (indicator group "Profitability") and invested capital (indicator group "Return on invested capital").

The above group is followed by the indicator groups "Sales/revenues" and "Costs/expenses" that classify indicators related to figures defined by the financial results of hotel enterprises. Although the researchers from the field of Financial Statement Analysis use figures arising from the financial results of each enterprise, still it is rather unusual for them to create indicator groups referring exclusively to sales, costs and expenses. The two exceptions were Kantzos (2013) and Niarchos (2004) who explicitly mention in their classifications the indicator group "Operating expenses". Nevertheless, it was considered necessary to incorporate the aforementioned two indicator groups (i.e. "Sales/revenues indicators" and "Costs/expenses indicators") in the classification of this study. On the one hand said groups are important for the determination of financial results and financial/economic performance of hotels and on the other hand it was observed that the literature related to hotel performance measurements emphasized the 
role of said figures-indicators (Assaf and Barros, 2011; Wu, Tsai and Zhou, 2011; Wadongo et al., 2010; Banker, Potter and Srinivasan, 2005; Haktanir and Harris, 2005; Parkan, 2005; Sharma and Upneja, 2005; Curry, 1985).

A significant indicator group in the case of hotel enterprises is "Hotel occupancy". This particular indicator group is of no interest for Financial Statement Analysis researchers. Even so, in the case of hotels, the "Occupancy rate" is a widely known and probably the most widely used indicator. It is no coincidence that its use is mentioned in 13 out of 79 papers (Ivanov and Zhechev, 2012; Assaf and Barros, 2011; Chen, 2011: Wu, Tsai and Zhou, 2011; Chen, 2010; Wadongo et al., 2010; ClaverCortes, Molina-Azorin and Pereira-Moliner, 2007; Claver-Cortes, Molina-Azorin and Pereira-Moliner, 2006; Banker, Potter and Srinivasan, 2005; Espino-Rodriguez and Padron-Robaina, 2005; Haktanir and Harris, 2005; Jeffrey and Hubbard, 1986; Curry, 1985). "Hotel occupancy rate" indicator is calculated based on the number of overnight stays/room nights and evaluates the utilization of the physical capacity of the hotel (Ivanov, 2014). "Hotel occupancy indicators" represent the financial performance of hotel enterprises and can be directly interpreted in revenues. For this reason they are closely monitored by hotel management. For the aforementioned reasons the researchers consider it necessary to record the "Hotel occupancy indicators" as a distinct group of financial performance for hotel enterprises.

Other groups of financial indicators include "Productivity", according to Bolat and Yılmaz (2009), as well as the group "Asset utilization or activity", according to Wild, Subramanyam and Halsey (2007); Niarchos (2004); Bernstein and Wild (1998). However, given that said groups describe -in a supplementary way- the ability and intensity of a firm to generate sales from its (human and other) resources, in the present classification it was considered necessary to merge the above groups into one group called "Productivity / utilization indicators".

Moreover, the group "Growth indicators" was adopted, as this was introduced by GarrigosSimon, Palacios-Marques and Narangajavana, 90
(2005) (and to a particular extent also by Wadongo et al. (2010) who named it "Competitiveness"). The group includes indicators that determine the perspectives and development of an enterprise. Another group that is interesting for hotels is the group "Financial market indicators". The above group, as it was presented by researchers from the field of Financial Statement Analysis (Kantzos, 2013; Wild, Subramanyam and Halsey, 2007; Niarchos, 2004; Bernstein and Wild, 1998), assesses the intrinsic value of a company and its stock. The indicator "Wealth creation" could be incorporated into the two last indicator groups. The reason for this is that, according to the researchers dealing with the measurement of hotel performance, the above indicator is incorporated into the group "Growth", whereas researchers from the field of Financial Statement Analysis classify it in the group "Financial market indicators". In the present classification, the researchers followed the model of the authors dealing with performance, thus incorporating the above indicator into the group "Growth", mainly due to the paper's focus in the hotel industry.

An important group of financial indicators is the group "Financial liquidity and soundness". Liquidity indicators are used to define the shortrun financial status of an enterprise and its ability to meet its short-term obligations (Niarchos, 2004). This group includes the indicators "Financial liquidity ratio" (Han, 2012; Palacios-Marques, Ribeiro-Soriano and GilPechuan, 2011), "Paying suppliers and creditors on time" (Wu, Tsai and Zhou, 2011; Wadongo et al., 2010), "Payback time" (Haktanir and Harris, 2005), as well as the indicator "Financial soundness" (PalaciosMarques, Ribeiro-Soriano and Gil-Pechuan, 2011).

It should be noted that, given the large investments required in the hospitality sector (Garcia de Soto-Camacho and VargasSanchez, 2015) the financial indicators and mainly the "Return on invested capital indicators" and "Profitability indicators" are crucial to hotel enterprises.

The suggested classification of financial indicators is completed by the establishment of the group "Composite indicators of economic 
performance". This group distinguishes itself from the others because it does not include indicators in a strict sense (as is the case with the rest of the groups) but rather it incorporates complex models of financial performance measurement. By establishing this special indicator group, the researchers tried to outline in their classification the tendency of some other researchers to use a "conglomeration", a set of indicators or a model in order to evaluate the financial performance of a hotel enterprise (Oliveira, Pedro and Marques, 2013; Assaf and Barros, 2011; Assaf and Cvelbar, 2011; Wu, Tsai and Zhou, 2011; Chen, 2010; Hsieh and Lin, 2010).

\section{Non-financial hotel performance indicators}

As regards non-financial or mainly qualitative indicators, the researchers who have dealt with the measurement of hotel performance divide them into a series of distinct groups (as opposed to financial indicators). Consequently, in the case of non-financial indicators, the classification suggested by the authors of this paper is largely based on previous classifications and groups arising from the international literature. Here, non-financial indicators have been divided into ten distinct groups (Table 1).

At the first stage takes place the distinction of the very important groups for the hospitality industry, i.e. "Customer satisfaction" and "Employee satisfaction". The researchers Garrigos-Simon, Palacios-Marques and Narangajavana (2005) incorporate the above parameters into the group "Stakeholder satisfaction". On the other hand, Chen, Hsu and Tzeng (2011); Bolat and Yılmaz (2009); and Espino-Rodriguez and Padron-Robaina (2005) distinguish between "Customer satisfaction indicators" and "Employee satisfaction indicators". These researchers create two different indicator groups, thus acknowledging their great importance for hotel enterprises. The classification of the present manuscript shares the same opinion.

Sharing the above point of view, the following groups were adopted, which refer to: a) the "Organizational effectiveness" in terms of achievement (according to the grouping of Bolat and Yılmaz, 2009); and b) the
"Competitive position" (according to GarrigosSimon, Palacios-Marques and Narangajavana, 2005). The two indicators "New customer increase rate" and "Hotel image" that were established by Chen, Hsu and Tzeng (2011) were also added to the above group, as they describe the competitive position of a hotel enterprise. Therefore, it is important that they are incorporated into this specific indicator group. Last but not least, a third group was also adopted, which refers to "Continuous improvement" (according to the grouping suggested by Bolat and Yılmaz, 2009). The above group was enriched by one more indicator, i.e. "Number of products and services innovated per year", which has been established by Wadongo et al. (2010) and illustrates the efforts of a hotel for continuous improvement of its products and services.

The researchers of this manuscript have identified and accepted as useful two more groups - "Social responsibility" (according to Bolat and Yılmaz, 2009) and "Community/environmental perspective" (according to Wadongo et al., 2010). Both the aforementioned groups include indicators relating to social and environmental awareness of hotel enterprises in the area where they operate. For this reason, the authors of the present manuscript have incorporated the indicators of the two groups mentioned above into a single indicator group called "Social responsibility". This group of indicators is significant for the image of hotel enterprises. Lim, Chong and Sutjipto (2012) and Bakhat, Rossello and Saenz-de-Miera (2010) recognize the need of a firm to be socially responsible for its business operations and to monitor the financial, as well as environmental and social sustainability in order to operate efficiently. From this point of view, "Social responsibility indicators" could be really useful.

Moreover, they have adopted an indicator group called "Flexibility", which has been established by Wadongo et al. (2010). There is a tendency of many other researchers (Karatepe, 2013; Li, Sanders and Frenkel, 2012; Gu and Chi Sen Siu, 2009; Mia and Patiar, 2008; Ogaard, Larsen and Marnburg, 2008; Umbreit, 1986) to measure the performance not only by means of particular 
single indicators but also by means of sets of indicators evaluating the individual qualitative performance. Thus the researchers of this paper established the indicator groups "Employee work/Job performance" and "Manager's work/Job performance", aiming at representing in their suggested classification the above tendency.

Finally, the indicator group "Service quality" was also incorporated in the classification. The above group includes just few indicators that have been suggested by Chen, Hsu and Tzeng (2011); Espino-Rodriguez and PadronRobaina (2005); Haktanir and Harris (2005). Still, these indicators are crucial as they deal with some quality parameters of the tourism product.

\section{Frequency of appearance of indicator groups in international literature}

The international scientific literature has 51 recorded financial indicators, which -according to the classification suggested here- can be divided into ten distinct groups (Table 1). The researchers focus mainly on the groups "Sales/revenues", "Profitability", "Return on invested capital" and "Hotel Occupancy", which are by far the most popular groups of financial indicators, as illustrated in column 4 of table 1. They are followed by the group "Cost/expenses" and then by the remaining five groups, which appear in fewer papers.

More specifically, the most known and widely used indicator is "Room or beds occupancy rate", which appears in the international literature more frequently than any other indicator, financial and non-financial (it was recorded in 13 out of 79 papers). It is followed by the indicators "ROA" and "ROI" belonging to the group "Return on invested capital" (recorded in 9 and 7 sources respectively) as well as by the indicators "Total revenue per available room" and "F\&B sales/revenue" (identified in 9 and 7 sources respectively), which stand out in the group "Sales/revenues". Here it is worth mentioning the following indicators as well: "Labor productivity" belonging to the group "Productivity/utilization"; "Stock return/Price earnings ratio" from the group "Financial market"; and "Sales/revenue growth" from the group "Growth" (recorded in 6 sources).

92
With regard to non-financial indicators, 68 indicators were recorded in the international literature, which are also divided into ten groups. The researchers have focused particularly on two indicator groups: "Customer satisfaction" and "Employee satisfaction" (recorded in 11 and 7 sources respectively) that are particularly important in the case of hotel enterprises. The rest eight groups appear in fewer articles (4 or less). From the indicator group "Customer satisfaction" the researchers interested in the measurement of hotel performance have mainly dealt with the indicator "Customer/guests' satisfaction" (recorded in 9 sources) and much less with the indicator "Guests' likelihood to return/Customer retention" (recorded in 4 articles). As regards "Employee satisfaction" the researchers focus mainly on "Turnover rates for employees/Voluntary turnover" (recorded in 6 sources) and on "Employee/personnel satisfaction" (recorded in 5 articles).

\section{Conclusion}

The objective of this manuscript is to classify the indicators used for the scientific measurement of hotel performance and to suggest a new codification and classification of said indicators. The Content Analysis of the studied papers led to the following main conclusion: Most researches dealing with the measurement of hotel performance could not reflect its multifaceted nature. This is mainly due to the fact that up to now in the vast majority of the cases hotel performance was not evaluated at the same time with several different indicators that would have revealed its multidimensional nature. More specifically, the use of the methodology and the exploitation of the existing scientific literature led to the following ascertainments: Hotel performance is a complex and multidimensional concept and as such it is reflected in the international literature in the form of many different measures or indicators used for scientific measurements. The researchers identified a large number and a great variety of measures and indicators recorded in the scientific measurement of hotel performance (in total 119 indicators: 51 financial and 68 non-financial). This means that the scientific research has still a long way to go before setting some defined and useful measures and indicators that will 
allow a scientific, still practical, measurement of hotel performance.

According to the above ascertainment, this manuscript attempts to suggest and put under the judgement of the scientific community a new codification of the existing indicators. Based on the proposed codification, said indicators can be divided into twenty distinct groups. In detail, these can be ten groups of financial indicators ("Sales/revenues", "Profitability", "Return on invested capital", "Hotel occupancy", "Costs/expenses", "Growth", "Financial market", "Productivity/utilization", "Composite indicators of economic performance" and "Financial liquidity and soundness") and ten groups of non-financial indicators ("Customer satisfaction", "Employee satisfaction", "Employee work/Job performance", "Continuous improvement", "Service quality", "Social responsibility", "Competitive position", "Manager's work/Job performance", "Flexibility", "Organizational achievement"). A main element of this codification is its holistic approach as regards the measurement of hotel performance and the use of financial and nonfinancial indicators.

In the majority of the studies so far, the researchers did not adequately present the multidimensional nature of hotel performance during the measurement. Consequently only few indicators were highlighted, which, however, could not properly define the nature and essence of performance, thus creating more confusion as regards its measurement. The frequency of appearance of the individual groups and their indicators in the literature reveals that, despite the long list of indicators and groups, the researchers tend to focus on a limited number of indicator groups. A typical example of this is that only five indicator groups have a frequency of appearance that exceeds ten papers. These are the groups "Sales/revenues", "Profitability", "Return on invested capital", "Hotel Occupancy" and "Customer satisfaction"; out of them only the last one concerns non-financial indicators. With regard to the rest of the indicators, most interest is focused on particular indicators ("Room or beds occupancy rate", "ROA", "Total revenue per available room" and
"Customer/guests' satisfaction") from which only the last one is a non-financial indicator.

\section{Industry implications}

The measurement of hotel performance is a highly multidimensional and multifaceted process that can be approached from many different perspectives. At the same time, it is a matter of utmost importance for hotel enterprises (Assaf and Cvelbar, 2011; Wu, Tsai and Zhou, 2011; Harris and Mongiello, 2001) as well as for executives working in the hospitality industry. There is a constant need for professionals to deal with the major issue of scientific hotel performance measurement in order to minimize its empirical estimation and measurement. Hotel managers must emphasize on the scientific measurement of performance in order to get useful information that has a major impact on making correct decisions at various levels and different issues, such as distribution of resources, focusing on particular activities, pricing, personnel compensation etc. Having studied a great number of scientific opinions and approaches, this manuscript proposes a new point of view of performance measurement and codification. One of its objectives is to give hotel managers a tool for easier information on, selection and implementation of the right indicators that can provide constant and accurate details on the performance of their hotels.

\section{Further research}

In order to improve the measurement of performance in the hotel sector, the authors make suggestions to researchers to use a variety of different measures. For example, according to its purpose, a study should include at the same time several indicators, financial and non-financial ones. This way researchers will be able to capture the multidimensional nature of hotel performance upon its measurement in their study. The present manuscript constitutes a theoretical research of indicators used for the scientific measurement of hotel performance. Still, the complex nature of performance itself in combination with the great importance that its measurement has for hotel enterprises render it necessary for future researches to further study, classify and present the various approaches and methods used in the empirical international researches 
for the measurement of hotel performance. In particular, it is recommended to study the following parameters:

- Which indicators are used in everyday operation of hotels?

- To what extent do systematic measurements or monitoring of performance take place?

- Which techniques are used for measuring performance?

- What dimensions of performance are actually recorded and according to which indicators?

Such a study would allow reaching more detailed conclusions on the entire approach of the measurement of hotel performance. At the same time, such an effort could also be used for the scientific measurement of performance in other industries, thus drawing useful conclusions and reaching comparative results.

The proposed new codification and classification of the indicators measuring hotel performance could also be a foundation for broad-spectrum scientific researches, for example researches focussing on investigating the relation between performance and other vital parameters of hotel management. Said scientific attempts could study the correlation between hotel performance and human resources management issues (e.g. compensation of personnel issues); strategic orientation issues; marketing issues; service and process improvement issues etc.

\section{References}

Assaf, A. G., C. Barros (2011) Performance analysis of the gulf hotel industry: A Malmquist index with bias correction. International Journal of Hospitality Management 30, 819-826

Assaf, A., K. L. Cvelbar (2011) Privatization, market competition, international attractiveness, management tenure and hotel performance: Evidence from Slovenia. International Journal of Hospitality Management 30, 391-397

Assaf, A. G., A. Josiassen, K. L. Cvelbar (2012) Does triple bottom line reporting improve hotel performance? International Journal of Hospitality Management 31, 596-600
Atkinson, H., J. Brander Brown (2001) Rethinking performance measures: Assessing progress in UK hotels. International Journal of Contemporary Hospitality Management 13 (3), 128-135

Bakhat, M., J. Rosselló, O. Saenz-de-Miera (2010) Developing a daily indicator for evaluating the impacts of tourism in isolated regions. European Journal of Tourism Research 3 (2), 114-118

Banker, R., G. Potter, D. Srinivasan (2005) Association of nonfinancial performance measures with the financial performance of a lodging chain. Cornell Hotel and Restaurant Administration Quarterly 46, 394-412

Beckert, J., K. Walsh (1991) Development plans replace performance reviews at Harvey Hotels: Emphasis on personal development, individual abilities and achieving goals creates sharper employees, better managers and superior guest service. Cornell Hotel and Restaurant Administration Quarterly 32 (4), 72-80

Bernstein, L., J. Wild (1998) Financial statement analysis: Theory, application, and interpretation. Boston: Irwin/McGraw-Hill.

Bolat, T., O. Yılmaz (2009) The relationship between outsourcing and organizational performance: Is it myth or reality for the hotel sector? International Journal of Contemporary Hospitality Management 21 (1), 7-23

Brotherton, B., G. Adler (1999) An integrative approach to enhancing customer value and corporate performance in the international hotel industry. International Journal of Hospitality Management 18, 261-272

Chen, T. H. (2009) Performance measurement of an enterprise and business units with an application to a Taiwanese hotel chain. International Journal of Hospitality Management 28, 415-422

Chen, M. H. (2010) The economy, tourism growth and corporate performance in the Taiwanese hotel industry. Tourism Management 31, 665-675

Chen, M. H. (2011) The response of hotel performance to international tourism development and crisis events. International Journal of Hospitality Management 30, 200212 
Chen, F. H., T. S. Hsu, G. H. Tzeng (2011) A balanced scorecard approach to establish a performance evaluation and relationship model for hot spring hotels based on a hybrid MCDM model combining DEMATEL and ANP. International Journal of Hospitality Management 30, 908-932

Cheung, K., R. Law (1998) Hospitality service quality and the role of performance appraisal. Managing Service Quality 8 (6), 402-406.

Cho, S., R. Woods, S. Jang, M. Erdem (2006) Measuring the impact of human resource management practices on hospitality firms' performances. International Journal of Hospitality Management 25, 262-277

Choy, D. (1985) Forecasting hotel-industry performance. Tourism Management 6 (1), 4-7

Claver-Cortés, E., J. Molina-Azorin, J. PereiraMoliner (2006) Strategic groups in the hospitality industry: Intergroup and intragroup performance differences in Alicante, Spain. Tourism Management 27, 1101-1116

Claver-Cortés, E., J. Molina-Azorin, J. PereiraMoliner (2007) The impact of strategic behaviours on hotel performance. International Journal of Contemporary Hospitality Management 19 (1), 6-20

Connolly, P., G. McGing (2007) High performance work practices and competitive advantage in the Irish hospitality sector. International Journal of Contemporary Hospitality Management 19 (3), 201-210

Crotts, J., R. Ford, V. Heung, E. Ngai (2009) Organizational alignment and hospitality firm performance. International Journal of Culture, Tourism and Hospitality Research 3 (1), 3-12

Cruz, I. (2007) How might hospitality organizations optimize their performance measurement systems? International Journal of Contemporary Hospitality Management 19 (7), 574-588

Curry, S. (1985) The hotel sector in Tanzania: A comparison of operating performance. Tourism Management 6 (2), 95-105

Espino-Rodriguez, T., V. Padrón-Robaina (2005) A resource-based view of outsourcing and its implications for organizational performance in the hotel sector. Tourism Management 26, 707-721
Fisher, R., R. McPhail, G. Menghetti (2010) Linking employee attitudes and behaviors with business performance: A comparative analysis of hotels in Mexico and China. International Journal of Hospitality Management 29, 397-404

Fridson, M., F. Alvarez (2002) Financial statement analysis: A pracitioner's guide. New York: John Wiley \& Sons.

García de Soto-Camacho, E., A. VargasSánchez (2015) Choice of entry mode, strategic flexibility and performance of international strategy in hotel chains: An approach based on real options. European Journal of Tourism Research 9, 92-114

Garrigós-Simón, F., D. Palacios-Marqués, Y. Narangajavana (2005) Competitive strategies and performance in Spanish hospitality firms. International Journal of Contemporary Hospitality Management 17 (1), 22-38

Gomes, C., M. Yasin, J. Lisboa (2007) The effectiveness of hospitality service operations: Measurement and implementation concerns. International Journal of Contemporary Hospitality Management 19 (7), 560-573

Gray, B., S. Matear, P. Matheson (2000) Improving the performance of hospitality firms. International Journal of Contemporary Hospitality Management 12 (3), 149-155

Gu, Z., R. Chi Sen Siu (2009) Drivers of job satisfaction as related to work performance in Macao casino hotels: An investigation based on employee survey. International Journal of Contemporary Hospitality Management 21 (5), 561-578

Haktanir, M., P. Harris (2005) Performance measurement practice in an independent hotel context: A case study approach. International Journal of Contemporary Hospitality Management 17 (1), 39-50

Han, H. J. (2012) The relationship among corporate culture, strategic orientation, and financial performance. Cornell Hospitality Quarterly 53 (3), 207-219

Harris, P., M. Mongiello (2001) Key performance indicators in European hotel properties: General managers' choices and company profiles. International Journal of Contemporary Hospitality Management 13 (3), 120-127 
Hartline, M., K. Jones (1996) Employee performance cues in a hotel service environment: Influence on perceived service quality, value and word-of-mouth intentions. Journal of Business Research 35, 207-215

Hayes, D., A. Miller (2011) Revenue management for the hospitality industry. Hoboken, N. J.: John Wiley \& Sons.

Heide, M., K. Lærdal, K. Grønhaug (2009) Atmosphere as a tool for enhancing organizational performance: An exploratory study from the hospitality industry. European Journal of Marketing 43 (3), 305319

Hsieh, L. F., L. H. Lin (2010) A performance evaluation model for international tourist hotels in Taiwan: An application of the relational network DEA. International Journal of Hospitality Management 29, 14-24

Hult, T., D. Ketchen, D. Griffith, B. Chabowski, M. Hamman, B. Johnson Dykes, W. Pollitte, T. Cavusgil (2008) An Assessment of the Measurement of Performance in International Business Research. Journal of International Business Studies 39, 10641080

Israeli, A., A. Mohsin, B. Kumar (2011) Hospitality crisis management practices: The case of Indian luxury hotels. International Journal of Hospitality Management 30, 367-374

lun, J., X. Huang (2007) How to motivate your older employees to excel? The impact of commitment on older employees' performance in the hospitality industry. International Journal of Hospitality Management 26, 793-806

Ivanov, S. (2014) Hotel Revenue Management: From Theory to Practice. Varna: Zangador.

Ivanov, S., V. Zhechev (2012) Hotel revenue management - a critical literature review. Tourism 60 (2), 175-197

Jeffrey, D., N. Hubbard (1986) Temporal dimensions and regional patterns of hotel occupancy performance in England: A time series analysis of midweek and weekend occupancy rates in 266 hotels, in 1984 and 1985. International Journal of Hospitality Management 7 (1), 63-80

Jung, H. I. (2008) WACC as the touchstone performance indicator: The use of financial ratios as performance indicator - from operations to capital investments.
International Journal of Contemporary Hospitality Management 20 (6), 700-710

Kang, K., S. Lee, C. Huh (2010) Impacts of positive and negative corporate social responsibility activities on company performance in the hospitality industry. International Journal of Hospitality Management 29, 72-82

Kantzos, K. (2013) Financial statement analysis. Athens.

Kaplan, R., D. Norton (1992) The balanced scorecard: Measures that drive performance. Harvard Business Review 33 (7/8), 171-179

Karatepe, O. (2013) High-performance work practices and hotel employee performance: The mediation of work engagement. International Journal of Hospitality Management 32, 132-140

Karatepe, O. (2012) Perceived organizational support, career satisfaction, and performance outcomes: A study of hotel employees in Cameroon. International Journal of Contemporary Hospitality Management 24 (5), 735-752

Kim, W. G., M. Cho, R. Brymer (2013) Determinants affecting comprehensive property-level hotel performance: The moderating role of hotel type. International Journal of Hospitality Management 34, 404412

Kimes, S. (2009) Hotel revenue management in an economic downturn: Results of an international study. Cornell Hospitality Report 9 (12), 6-17

Klidas, A., P. Van den berg, C. Wilderom (2007) Managing employee empowerment in luxury hotels in Europe. International Journal of Service Industry Management 18 (1), 70-88

Kozak, M., M. Rimmington (1998) Benchmarking: destination attractiveness and small hospitality business performance. International Journal of Contemporary Hospitality Management 10 (5), 184-188

Krippendorff, K. (2013) Content analysis book: An introduction to its methodology. Los Angeles: Sage.

Krippendorff, K. (2004) Content analysis: An introduction to its methodology. California: Sage.

Lai, J., F. Yik (2012) Hotel engineering facilities: A case study of maintenance 
performance. International Journal of Hospitality Management 31, 229-235

Lee, S., W. Kim (2009) EVA, refined EVA, MVA, or traditional performance measures for the hospitality industry? International Journal of Hospitality Management 28, 439445

Li, X., K. Sanders, S. Frenkel (2012) How leader-member exchange, work engagement and HRM consistency explain Chinese luxury hotel employees' job performance. International Journal of Hospitality Management 31, 1059-1066

Lim, C., Y. Chong, M. Sutjipto (2012) Creating value through sustainable business practices. European Journal of Tourism Research 5 (2), 118-128

Maier, T. (2011) Hospitality industry revenue management performance modelling: Uncovering issues associated with inconsistencies in price parity across multiple distribution channels in the US hotel market. International Journal of Revenue Management 5 (4), 290-307

Marco, R. (2012) Gender and economic performance: Evidence from the Spanish hotel industry. International Journal of Hospitality Management 31, 981-989

Mauri, A. (2013) Hotel revenue management: Principles and practices. Pearson.

Mauri, A. (2007) Yield management and perceptions of fairness in the hotel business. International Review of Economics 54 (2), 284-293

Maxwell, G., G. Lyle (2002) Strategic hrm and business performance in the Hilton Group. International Journal of Contemporary Hospitality Management 14 (5), 251-252

Mia, L., A. Patiar (2008) The effect of subordinates' gender on the difference between self-ratings, and superiors' ratings, of subordinates' performance in hotels. International Journal of Hospitality Management 27, 53-64

Namasivayama, K., L. Miao, X. Zhao (2007) An investigation of the relationships between compensation practices and firm performance in the US hotel industry. International Journal of Hospitality Management 26, 574-587

Neves, J., S. Lourenco (2009) Using data envelopment analysis to select strategies that improve the performance of hotel companies. International Journal of Contemporary Hospitality Management 21 (6), 698-712

Niarchos, N. (2004) Financial statement analysis. Athens: Stamoulis.

Ogaard, T., S. Larsen, E. Marnburg (2008) Perceptions of organizational structure in the hospitality industry: Consequences for commitment, job satisfaction and perceived performance. Tourism Management 29, 661-671

Oh, H., M. Jeong (2010) Evaluating stability of the performance-satisfaction relationship across selected lodging market segments. International Journal of Contemporary Hospitality Management 22 (7), 953-974

Oliveira, R., M. I., Pedro, R. Marques (2013) Efficiency and its determinants in Portuguese hotels in the Algarve. Tourism Management 36, 641-649

Palacios-Marqués, D., D. Ribeiro-Soriano, I. Gil-Pechuán (2011) The effect of learningbased distinctive competencies on firm performance: A study of Spanish hospitality firms. Cornell Hospitality Quarterly 52 (2), 102-110

Parkan, C. (2005) Benchmarking operational performance: The case of two hotels. International Journal of Productivity and Performance Management 54 (8), 679-696

Peacock, M. (1995) A job well done: Hospitality managers and success. International Journal of Contemporary Hospitality Management 7 (2), 48-51

Phillips, P. (1999a) Hotel performance and competitive advantage: A contingency approach. International Journal of Contemporary Hospitality Management 11 (7), 359-365

Phillips, P. (1999b) Performance measurement systems and hotels: A new conceptual framework. International Journal of Hospitality Management 18, 171-182

Pine, R., P. Phillips (2005) Performance comparisons of hotels in China. International Journal of Hospitality Management 24, 57-73

Pollitt, D. (2006) Red Carnation blooms through management training: Morale improves and employee turnover falls at boutique hotel group. Human Resource Management International Digest 14 (6), 11-14 
Rahman, D. H. A. A., A.M. Dayang-Affizzah, S. Edman (2012) Tourism and hotels in Sarawak: Economic performance. ProcediaSocial and behavioral sciences 65, 10201026

Ratsimbanierana, H., S. Sbai, A. Stenger (2013) Moroccan tourist portfolio efficiency with the mean-variance approach. European Journal of Tourism Research 6 (2), 122-131

Ryan, C., G. Huimin (2007) Perceptions of Chinese hotels. Cornell Hotel and Restaurant Administration Quarterly 48 (4), 390-391

Sainaghi, R. (2010) Hotel performance: State of the art. International Journal of Contemporary Hospitality Management 22 (7), 920-952

Sainaghi, R. (2011) RevPAR determinants of individual hotels: Evidences from Milan. International Journal of Contemporary Hospitality Management 23 (3), 297-311

Sainaghi, R., P. Phillps, V. Corti (2013) Measuring Hotel Performance: Using a Balanced Scorecard Perspectives' Approach. International Journal of Hospitality Management 34 (1), 150-159.

Sharma, A., A. Upneja (2005) Factors influencing financial performance of small hotels in Tanzania. International Journal of Contemporary Hospitality Management 17 (6), 504-515

Sigala, M., K. Chalkiti (2007) Improving performance through tacit knowledge externalization and utilization: Preliminary findings from Greek hotels. International Journal of Productivity and Performance Management 56 (5), 456-483

Sina, L., A. Tse, V. Heung, F. Yim (2005) An analysis of the relationship between market orientation and business performance in the hotel industry. International Journal of Hospitality Management 24, 555-577

Sourouklis, C., D. Tsagdis (2013) Workforce diversity and hotel performance: A systematic review and synthesis of the international empirical evidence. International Journal of Hospitality Management 34, 394-403

Southern, G. (1999) A systems approach to performance measurement in hospitality. International Journal of Contemporary Hospitality Management 11 (7), 366-376
Sozuer, A. (2011) Self assessment as a gate to performance improvement: A study on hospitality management in Turkey. Procedia-Social and behavioral sciences 24 , 1090-1097

Teare, R. (1996) Hospitality operations: Patterns in management, service improvement and business performance. International Journal of Contemporary Hospitality Management 8 (7), 63-74

Tsai, C. H., S. J. Chen, S. C. Fang (2009) Employment modes, high-performance work practices, and organizational performance in the hospitality industry. Cornell Hospitality Quarterly 50 (4), 413-431

Umbreit, T. (1986) Developing behaviorallyanchored scales for evaluating job performance of hotel managers. International Journal of Hospitality Management 5 (2), 55-61

Venkatraman, N., V. Ramanujam (1986) Measurement of Business Performance in Strategy Research: A comparison of approaches. Academy of Management Review 11 (4), 801-814

Wadongo, B., E. Odhuno, O. Kambona, L. Othuon (2010) Key performance indicators in the Kenyan hospitality industry: A managerial perspective. Benchmarking: An international journal 17 (6), 858-875

Werner, S., S. Ward (2004) Recent compensation research: An eclectic review. Human Resource Management Review 14, 201-227

Wild, J., K. Subramanyam, R. Halsey (2007) Financial statement analysis. London: McGraw-Hill//rwin.

Wu, J., H. Tsai, Z. Zhou (2011) Improving efficiency in international tourist hotels in Taipei using a non-radial DEA model. International Journal of Contemporary Hospitality Management 23 (1), 66-83

Xiao, Q., J. O'Neill, A. Mattila (2012) The role of hotel owners: The influence of corporate strategies on hotel performance. International Journal of Contemporary Hospitality Management 24 (1), 122-139

Yu, M. M., B. Lee (2009) Efficiency and effectiveness of service business: Evidence from international tourist hotels in Taiwan. Tourism Management 30, 571580 